\title{
Leikki innostaa oppimaan myös korkeakoulukirjastoissa - Innovointi edellyttää uskallusta epäonnistua
}

Kysymykset: Eerika Kiuru ja Janika Asplund

Pelillisyyttä informaatiolukutaidon ohjauksessa tutkiva ja kokeileva Andrew Walsh vieraili Helsingissä keväällä 2017. Hän kävi Suomen tieteellisen kirjastoseuran kutsumana tutustuttamassa suomalaisia kirjastoammattilaisia pelien hyödyntämiseen informaatiolukutaidon opetuksessa. Making educational escape room style activities -työpajan aiheena oli mysteerihuo- neen hyödyntäminen opetustilanteissa. Työpajassa osallistujat rakensivat prototyypin omasta informaatiolukutaito-aiheisesta mysteerihuoneestaan. Päivä oli hauska ja ohjelmarakenne osallistava. Oli myös havainnollista ja inspiroivaa tutustua Andrew'n mukanaan tuomaan oheisrekvisiittaan, kuten erilaisiin lukkoihin ja sana-arvoituksiin.

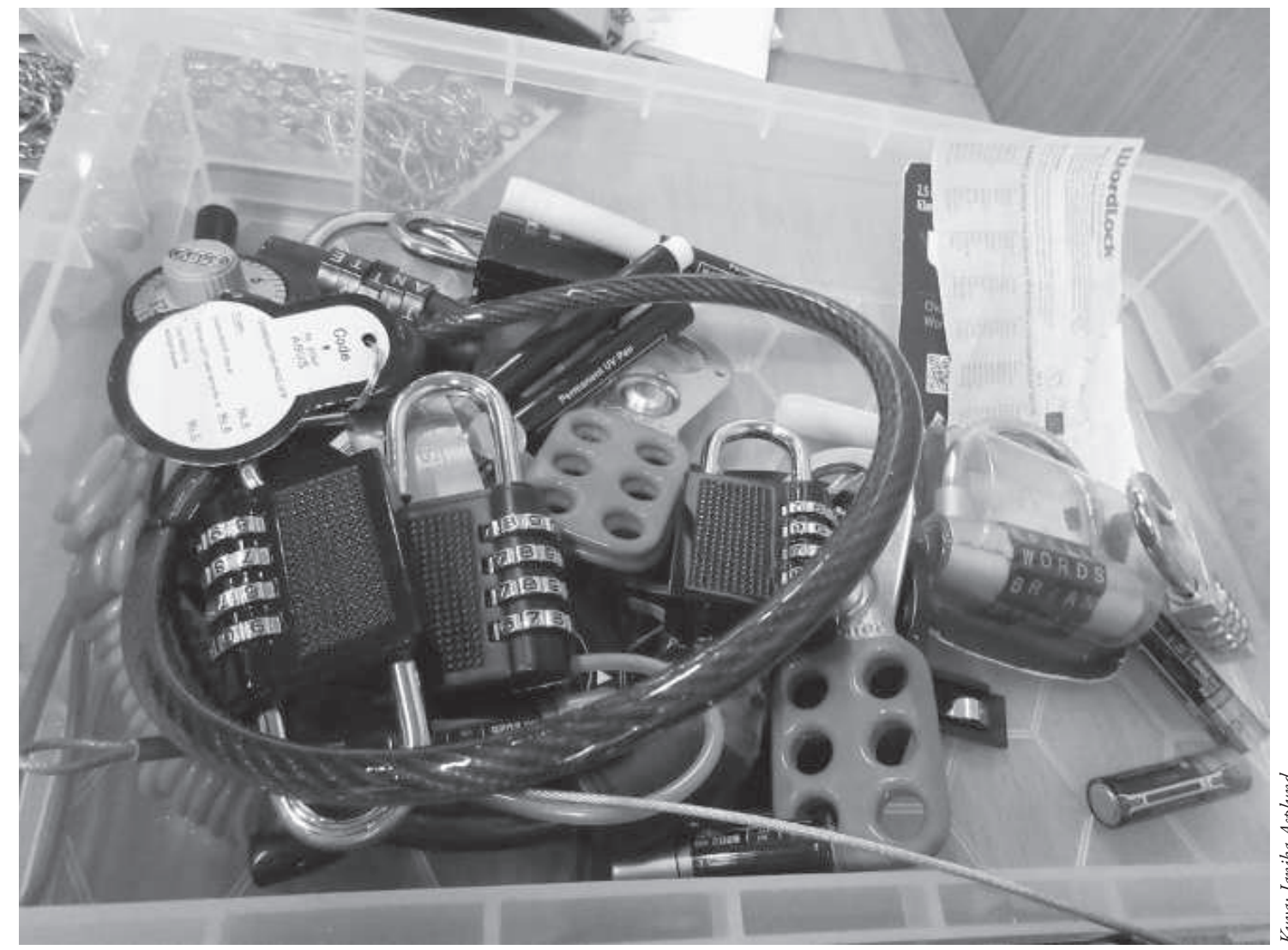

Mysteerihuoneen rakennusmateriaaleja. 
Työpajan jälkeen haastattelimme Andrew'ta. Pyysimmehäntä reflektoimaan koulutusta ja kertomaan ajatuksiaan informaatiolukutaidon opetuksen kehittämisestä.

Andrew'n vastaukset herättävät paljon ajatuksia. Mysteerihuoneet eivät ole pelkästään väline tai opetustekniikka. Niillä voidaan saada ihminen oppimiselle otolliseen vireeseen. Leikki ja pelit eivät ole vain lasten etuoikeus, vaan leikilli- nen olotila ja tarinallisuus edesauttavat myös aikuisen oppimista.

Andrew'n mukaan opetusta suunniteltaessa pitäisi olla lupa ja uskallusta tehdä virheitä tai epäonnistua. Voisiko näistä ajatuksista olla hyötyä pedagogisen johtamisen näkökulmasta? Lisää voit lukea Andrew’n englanninkielisestä haastattelusta.

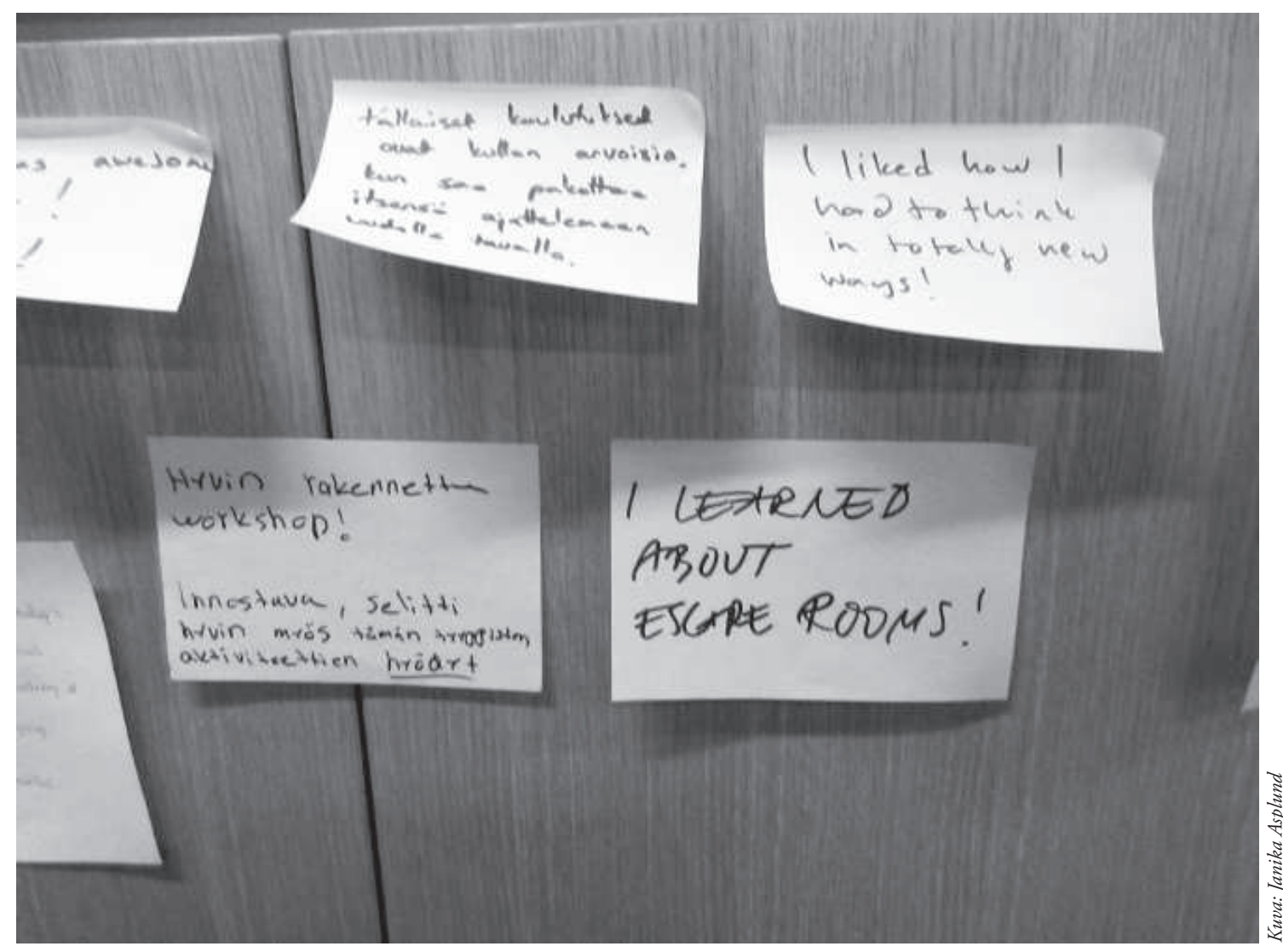

Palautetta päivästä. 